\title{
The Role of Queenrides Platform in Safety Riding Education and Women Empowerment During The Covid-19 Pandemic Era
}

\author{
$1^{\text {st }}$ Isnawati $^{1}, 2^{\text {nd }}$ Muhammad Yusuf $^{2}, 3^{\text {rd }}$ Imam Sujoko $^{3}$ \\ \{isnawati17@mhsuinjkt.ac.id ${ }^{1}$, muhammadyusuf17@mhs.uinjkt.ac.id², imamsujoko@uinjkt.ac.id ${ }^{3}$ \}
}

UIN Syarif Hidayatullah Jakarta ${ }^{1,2,3}$

\begin{abstract}
This study discussed the role of Queenrides as a safety riding education platform for empowering women during the pandemic era. This research was a qualitative study using descriptive analysis. The primary data sources were taken from the results of interviews with the founder of Queenrides Indonesia, websites, social media accounts, and overview documents compiled by the Queenrides team. Furthermore, the secondary data used were some relevant previous studies. This research revealed that apart from being a safety riding education platform for women, a significant role in empowering women was implemented by Queenrides through giving lecturers using WhatsApp media for several themes such as the economy (business), digital literacy, mental health, and family life education. The number of participants was doubled during the pandemic period.
\end{abstract}

Keywords: Education, Empowerment, Pandemic, Safety Riding, Women.

\section{Introduction}

In this modern era, transportation played an important role in supporting society's growth and welfare in various fields. The development of transportation was accelerated by advances in science and technology increasing the rate of growth of vehicles [13]. Based on the Central Statistics Agency, the number of motorcycles for 3 years from 2017-2019 increased significantly. In 2017, there were 100,200,245 units of vehicles used. Furthermore, $106,657,952$ units were distributed in 2008. Additionally, 112,771,136 units were produced in 2009 [37].

The increasing number of vehicles as a means of transportation gave a positive impact to fulfill and improve human welfare, especially as a mobilization medium facilitating people's daily activities. However, it was also accompanied by some negative effects such as congestion and the increasing number of traffic accidents [13]. Based on Global Status Report on Road Safety given by WHO in 2014, Indonesia became a country with the fastest growth for road accident numbers in the world which increased up to $80 \%$. Three people died every hour due to road accidents [39]. 87.5\% of mishaps occurred because of the driver's bad behavior. Additionally, the ratio of road accident numbers between male and female were 5:2. About $49.5 \%$ of motorcycle accidents involved women. However, $80 \%$ of Indonesian women drove to work to support their families.

Women drivers were fragile victims of road crimes. Therefore, they were vital to being conscious for understanding safety riding. The mentioned data were several reasons that 
encouraged Iim Fahima to create Queenrides [38]. To reduce the number of women driver accidents, some campaign programs aimed at empowering women to understand and apply safety riding were held. The program was significant since one of the countries with the best safety riding in the world, Australia, mentioned that women naturally did not have enough skills to drive like men [38].

Queenrides was a social enterprise technology-based start-up, using an online and offline platform built to empower women to be aware of the importance of driving safely. To improve women's skills and confidence in driving, Queenrides conducted the program more effectively using a positive approach that touched the participants' hearts. Queenrides was geared to support a movement from women to women with the \#WomenRideSafe campaign. Through this campaign, female drivers were highlighted about the significance of safe driving. By protecting and keeping themselves on the road, they also saved their children, spouse, family, and even the surrounding people [38].

To be widely accepted by women, the slogan "Safety, Style \& Beauty" was carried to complement other relevant issues for women driving cases. Aside from online-based education, some offline activities were made, including the "Ngopi Cantik" event in which women riders and communities discussed and shared some issues. By understanding safety riding insights, women could not only care for themselves and their closest people but also became agents of change. Thousands of members and more than 200 thousand communities spread throughout Indonesia had become part of the Queenrides' movement which would continue to roll into a global movement [38].

Based on the interview, Iim Fahima said that Queenrides was built because of the high number of road accidents among women, while the current approach for the road safety issue was too masculine and not gender-based. According to her, the high number of woman accidents required a special approach to solve. Therefore, Queenrides used a "safety, style, and beauty" approach. With this approach, she collaborated with many parties, corporations, and also the government from various ministries. Even Jokowi had also participated to support this campaign.

Since its establishment in 2016, 200 thousand women in Indonesia had been involved in the programs. Recently, 9 thousand women had joined offline safety riding education. Iim also added that the number of female riders increased by $42 \%$ in the last four years. However, the number of female drivers involved in road accidents increased $49.5 \%$. Based on this condition, according to Iim, safety riding education was significant to be done regularly for female drivers.

Based on a survey involving 3,500 female drivers, $80 \%$ of them were the breadwinners of their families. Then, $95 \%$ of respondents admitted that the driver's license (SIM) was obtained illegally. Not surprisingly, the Indonesian Police Traffic Corps (Korlantas Polri) reported that two of the five drivers involved in the road accident were women. Those facts reinforced Queenrides' focus and purpose to solve the problems [40].

Several pieces of training for female drivers in several cities in Indonesia were regularly held. An official website containing various tips for safe driving, passing online SIM C and A tests and giving information about events such as touring, seminars, and training was also maintained by Queenrides.

Although this start-up was seen as a place for safety riding education for women, in fact, the members also learned other issues such as good lifestyle, family planning, financial management, and sexual health that could be applied in their respective families. This kind of training might be difficult to obtain for women workers, but this start-up accommodated them to get several key insights at once. 
In a wider reach, during the pandemic time, Queenrides did not only provide online workshops for its members but also opened the program for the public. Based on the data from the Queenrides Instagram social media account, 40 themes were discussed in the forums included business and self-development for women, parenting, and child education. Most of the discussions were finished through online lectures using WhatsApp and Zoom

A post on Queenridesindonesia's Instagram account on July 13, 2020, told that the discussions had been followed by 5.000 women from Indonesia and several other countries such as Hong Kong, Malaysia, and Australia learning about parenting and business. The main capitals to be an empowered woman were knowledge and money. With these two things, women could stand firmly on their own feet. Even if they had a rich husband, women should have their income and continue to enrich knowledge for themselves, their families, and the environment (Instagram Queenridesindonesia).

Interestingly, Queenrides did not determine the registration fee for participants. They only needed to pay as much as they could. However, for workshops that contained several sessions at once, Queenrides provided a tariff while still providing discounts for Queenrides members or the general public who had ever attended previous workshops. A real role was given by Queenrides as a step to educate many women in Indonesia. A community called Pojok Queenrides was also created as a group focusing on mental health and family education. Consultation sessions personally and sharing issues guided by psychologists were also held by this start-up.

Pandemic became a new era that required a lot of adjustment and knowledge, especially for women. Almost everyone got stressed during this time. They had to face a changed system such as working from home and having children attending school from home, which required them to take care of themselves more carefully. As a step to help women to stay physically and mentally healthy as well as be able to be good educators, Queenrides offered a variety of affordable workshops using WhatsApp media that could be accessed by anyone from anywhere without space restrictions. Based on the explanation above, the author was interested to conduct this research and reveal the role of Queenrides in those two essential issues to support Indonesian women in Indonesia for being educated and protected when driving.

Women empowerment was discussed continuously in many forums for many years. From 1975 to 1985, the results of the decisions of the first women's conference in Mexico City had encouraged the United Nations as the highest organization in the world to include women issues, not only into the social and humanitarian commission but were also discussed in the cooperation commission and development [23].

In Indonesia, President's Instruction No. 9 of 2000 on PUG (Gender Mainstreaming) and various laws related to women as well as commitments to international agreements had prompted a paradigm shift in women's empowerment, namely from WID (Women in Development) to GAD (Gender and Development). The difference between the two was that WID launched development programs and activities only for women, while GAD tried to understand women's subordination through gender analysis [10]. Gender relations were a way in which a culture or society defined the rights, responsibilities, and identities of men and women in their communication relationships [2].

Five levels of equity were arranged in the women empowerment framework, namely equitable levels of welfare, access, awareness, participation, and control [23]. If women were not economically empowered, they did not have opportunities to improve their economic welfare. Women should also have access to good information, job opportunities, and education. After being economically empowered and gaining access, awareness emerged 
which hopefully could improve their quality of life. Furthermore, an equal distribution of active participation should also be provided where women were no longer considered as targets or objects but participated and played an active role in running programs. The last stage was power distribution for supporting women to contribute at the decision level. This stage certainly had an impact on women's empowerment. If this participation was used, their access to economic resources could be better to ensure equal distribution of access to resources and benefit-sharing.

Women's Studies Encyclopedia explained that gender was a set of attitudes, roles, functions, and responsibilities inherent in men and women shaped by culture and the influence of the social environment in which they grow and were raised [33]. Gender could be interpreted as a cultural expectation of men and women [12]. Additionally, gender in this sense was formed socially, not naturally [16].

Feminist groups in London began to introduce the term gender as a sociological concept in the second half of the 20th century in 1977 [28]. In this context, gender was defined as more than just a distinction between men and women from a socio-cultural perspective, but was interpreted as an analytical concept in understanding and explaining something. This perception reinforced gender analysis theory as a new analysis method [17]. Gender analysis was a new lens to add and complement the previous social analysis [7].

Gender was often equated with sex. Sex was the difference between men and women biologically that had been determined by Allah SWT while gender was the difference between the two determined by society. Because gender and sex were often equated, the injustice in treating men and women still occurred related to something that still could be struggled for to be considered as a destiny. Even, when women questioned something, they considered suing destiny [21]. Gender awareness was significant to distinguish between men and women socially.

One of the serious challenges to realizing gender justice was the dichotomous perspective on men and women. Men and women were different so they were seen as contradicting each other in which a party should be defeated. In this context, the patriarchal system had a big role to shape that perception. Men were considered as superior beings, while women were inferior and should be men's servants. The women's value was determined by the extent to which they served the men [7]. In line with this concept, Quraish Shihab, a well-known Indonesian commentator, said that inequality was easily found in real social life [26]. Whereas in the Qur'an, it was explicitly stated that women had an honorable position [27].

A fundamental difference between gender as a topic and as a perspective had emerged. When viewed as a topic, gender might be something that discussed the relationship between men and women exclusively. Considering that unequal gender relations often placed women in a lower position, special attention to women was central to balance these relations. Finally, that fact became a reason for gender to be often understood as an identical issue with women [21].

At what time gender was used as a perspective, this term became inclusive. As a perspective, gender was likened to be a lens attached to the eye. It was significant to use in looking at everything. Lies Marcoes, a gender activist and expert, said that gender was a complementary lens for various other lenses such as the lens of humanity, nationality, Islam, justice, and benefit. Using a gender lens, some questions were given when talking about anything, namely: Is the formulation humane, fair, and beneficial for women? Does this formulation not cause women to get sicker while undergoing women's biological experiences? Does this formulation not cause women to experience gender injustice? [21]. 
Therefore, a gender lens could also be used to understand a very broad system of life [21]. Anyone, regardless of gender, was obliged to uphold justice and respect every individual, including women. Women had the right to demand justice and equality from a hostile social system [31]. Justice was the most central idea as well as the highest goal taught by every religion to achieve the ideals, hopes, and dreams of every human being in all aspects, such as in the family, community, and state life [30].

\section{Methodology}

This research was a qualitative study using an analytical approach to know the role of Queenrides in educating women about safety riding and empowering them during the pandemic period. For conducting research analysis, some data sources were needed for this study [1]. The data were divided into two types, namely primary and secondary data sources [16]. The primary data were obtained directly from the main source of research [3], while secondary data sources were taken from previous research or other literature [8].

The primary data in this study were the results of direct interviews with the founder of Queenrides, Iim Fahima Jachja. In addition, some overview documents compiled by the founder and the team, as well as data on the website and Queenrides social media accounts were also used as the main data. The secondary data were the previous literature relevant to the discussed theme.

The data collection method applied was field research through interviews [32] with a key informant namely the founder of Queenrides. The document analysis was also employed by analyzing Queenrides' website and social media accounts (Instagram, Facebook, and Twitter). In addition, a literature analysis was also completed [16] using relevant studies related to safety riding, women empowerment, and the Covid-19 pandemic issues. The technique used to analyze and present the data was the descriptive-analytical method, through explaining the data and facts collected from the field and then analyzing them according to the research objectives [22].

\section{Result and Discussion}

\subsection{Queenrides Indonesia}

Queenrides is an online and offline women empowerment platform that focuses on women rider safety, women economic empowerment, digital literacy, and family life education. The online channel of Queenrides is website, Instagram, Facebook, Twitter, and Youtube. The campaign of Queenrides is using a high fashion approach to create word of mouth to disrupt the regular safety riding campaign. During Pandemic, Queenrides build a team consisting of Psychologists, Education Experts, Entrepreneurs, Lawyers, and Business Trainers who have been empowering more than 10.000 women and men via kulwap (kuliah via Whatsapp) to learn about business, leadership, children education, and also parenting.

Iim Fahima Jachja as the founder of Queenrides is a Young Global Leader of World Economic Forum and Founder and CEO of Queenrides, an online-offline women empowerment community platform with four pillars: Road Safety, Economic Empowerment, Digital Literacy, and Family Life Education. Having more than $400 \mathrm{~K}$ communities all over 
Indonesia with strong engagement, routine, and well-planned activities, Queenrides is now a collaboration platform for public, private sectors, NGOs, and also Government. In 2018, Queenrides was selected by The World Economic Forum as one of the leading startups of the ASEAN region.

Her educational background was Broadcasting Academy Jakarta (1995-1997), Lee Kuan Yew School of Public Policy National University of Singapore (2017), and Harvard Kennedy School (2018). Iim is an active speaker at numerous international events such as World Economic Forum Davos, World Economic Forum The Annual Meeting of New Champions China, FIA The Fédération Internationale de l'Automobile Regional Conference, Nissan Future, and many more. Iim also often invited by magazines, radio stations, and television stations to be the speaker for Mobility, Startups, Entrepreneurship, and Women-related issues. Iim was a panelist at World Economic Forum Davos 2019, to discuss the future of global transportation and the automotive industry in the Fourth Industrial Revolution during the How Autonomous Vehicles Earn Trust session, alongside other prominent figures including The President of The Fédération Internationale de l'Automobile, Jean Todt, and a member of Volkswagen's board of management, Andreas Renschler. Iim was also named among 2019 World Economic Forum's Young World-Changer by the Forum.

Before Queenrides, Iim was a significant role in the digital advertising industry. Founder and CEO Virus Communication who brought the trend of digital advertising to Indonesia in 2005, the company won many pitches local and regional. In $2011 \mathrm{Iim}$ was appointed CEO of Virtual Consulting (VIRTUCO) that owns Musikkamu.com with 20 million paid subscribers; Gila Motor, media with the most engaged online-offline motorbike community with 700.000 members.

Iim Fahima Iim Fahima received several awards and nominations such as Young Global Leader of World Economic Forum, Davos. Mentioned as Young World-Changer at the 2019 annual meeting of the World Economic Forum in Davos. Leading Startups in ASEAN Region 2018 by The World Economic Forum (Queenrides). 10 Indonesia Young Leaders who received President Jokowi Biography from the President himself. 10 Most Innovative Social Movement 2016 by Tempo Newspaper (Queenrides) and others.

\subsection{The Role of Queenrides platform in empowering women during the pandemic period}

Based on the results of the author's virtual interview via Zoom with Iim Fahima as the founder of Queenrides, the focus of the platform she founded was educating women about safety riding. During conducting training on safety riding, Queenrides collaborated with many parties such as the government (Ministry of Finance), Gojek, and others. These collaborations were done to ensure that the public could easily access the training. In two years, this community had grown to have hundreds of thousands of members throughout Indonesia [36].

When the pandemic occurred, almost all activities should be carried out online and remotely. This moment was difficult since training on safety riding could not be completely done using online media as the offline approach was more effective. Because of that condition, Queenrides finally entered another area that had been planned, such as economic and family empowerment, said Iim Fahima (Interview).

Because the community and brand had been well known and achieved high awareness and support from the public, the movements carried out by Queenrides developed well, empowering this start-up to be easier in carrying out various kinds of positive actions. For 2 years before the pandemic, road safety training held only reached around 4000 people from all 
over Indonesia. However, during the pandemic period, using an online approach by Zoom, and WhatsApp, the Queenrides group events were followed by around more than 10,000 women. Its members continued to grow not only from Indonesia but also from 20 other countries. In conclusion, during the pandemic time, Queenrides' participants were doubled.

Based on the Queenrides Indonesia Instagram social media account, 37 different themes were offered to be discussed during the pandemic time. Some speakers and experts were involved to share their knowledge. Some forums were led by the founder of Queenrides, Iim Fahima Jachja, but the rest were handled by other speakers that collaborate with this start-up. The speakers were experts from the relevant topic discussed.

This study categorized the themes discussed in the Queenrides online workshop into 2 major groups, namely:

a. Business and Self-development

The theme covered how to start a business, find ideas and turn them into business opportunities, grow businesswomen's mindset and mentality, create a business vision and mission, calculate production cost, manage financial affairs for novice businessmen, build marketing strategies, arrange sales strategy on social media, and optimize basic social media ads.

Based on observation conducted through joining a session talking about business led by the founder of Quuenrides, Iim Fahima Jachja on February 28, 2020, materials were delivered using understandable language for beginners. The content was short, and then followed by a question and answer session.

The WhatsApp lecturing and workshops organized by Queenrides offered basic themes to more complex ones covering substantial and even technical explanations. The participants were taught how to find ideas and turn them into business opportunities, grow a business mindset at home, and prepare the entrepreneur mentality. After that, they were shown how to create a business vision and mission, arrange successful sales strategies on social media, and optimize basic social media ads, and social media marketing, as well as build marketing strategies. In addition, they also learn how to manage their finance that was significant for their business, related to how to calculate production cost and financial management for a novice business.

The next material related to self-development was how to build a sense of purpose. Sense of purpose was defined as a motivation that drove a person towards a bright future and helped to get benefits optimally. Another theme discussed was how to keep being resilient in facing various pressures. This was a basic skill that should be owned by a businesswoman, especially during the pandemic period. This endurance did not mean that women just stayed in the discomfort zone for a long time, but they should survive by continuing to move forward rationally and purposefully. Resilience, stress tolerance, and flexibility were mentioned by the World Economic Forum as basic skills that should be owned by someone to be successful in the future. These three characters did not emerge since women were birth, but they should be built and continuously trained by understanding others' uniqueness. This self-understanding factor was central because each individual was unique and had a different way of responding to stress and difficult times.

In teaching women to be resilient, Queenrides used a good approach. The speaker said that tough times were like a scale. On a side, the burden was very heavy; on the other hand, the other side was light. Between the two sides of the scale, a middle point was called the "Fulcrum" or pivot point, the main point that determined where the scale would move. The person's position when facing a difficult time was like the position of the Fulcrum, a position that determined where their life moved. To move the scales, resilience, stress tolerance, and 
flexibility skills were needed. Specifically, this theme was usually discussed in 8 meetings using WhatsApp media regarding the steps to build resilience, stress tolerance, and flexibility were guided by a Clinical Psychologist, Faiz Hayaza.

A session that discussed how to manage stress while working from home was also given. Stress management was especially significant for working women during the pandemic time where the work demands, household conditions, children's affairs, spouse, friends, and relatives, had the potentials to make stress. Stress management needed to be learned seriously because the impact of stress could damage many things and reduce the individuals' physical, work, and life quality. Stress was also contagious. So, if a person's stress was not managed, her surrounding people could be influenced to become uncomfortable which can lead to a decrease in their performance. A stressed leader caused her team to get stressed too. Stressed parents transmitted their feelings to their children.

Dealing with the pandemic time, Queenrides also offered a session discussing how to maintain mental health. Mental health cases increased and occurred in all ages from children to adults. Parents were vital to understanding this issue because they played a major role to create a calm and conformable situation at home. Mentally healthy parents presented a healthy home for their children. In the smallest scope, the home was a safe zone for children to tell stories and vent their feelings without being judged and blamed.

Furthermore, some sessions talking about personal branding strategies and creative writing for beginners were also provided. The personal branding strategy was presented in a training program for three meetings via WhatsApp which consisted of building a brand image, understanding core values, understanding personality, and competency mapping, and building a digital web and social media footprint. This concept was related to positive and relevant information that people would like to show to others when they were read or found by the public on the internet. Personal branding was not an image that arose from the results of free writings, but it was related to how to bring out one's experience and expertise in a field to enable many people for recognizing it, increase public's trust, improve collaboration/business opportunities, and supporting individuals to be accepted in the dreamed company and achieve their goals. Someone with good personal branding had a much higher perceived value compared to those who did not have it.

Another skill needed in the internet era was the ability to create interesting narratives that touched readers' emotions, commonly called "Creative Writing". This skill was a must for all professions that used social media to spread messages.

b. Parenting and Child Education

In this digital age, parenting had tremendous challenges. Parents were required to have digital knowledge and wisdom for understanding digital technology and how to use it wisely. The Internet brought both advantages and disadvantages. The internet was a vast jungle. Millions of people with various characters and billions of information were encountered.

Aside from children, many parents even lost their control to use the internet. They got an addiction to online games, being involved, or being a victim of online bullying, hoaxes, and pornography. They were a few challenges in the vast jungle of the internet that children encountered every day (@Queenridesindonesia). As a preventive way to anticipate unwanted things, Queenrides provided several workshops using WhatsApp media to talk about parenting in the digital era, with some sub-themes such as seven parenting concepts in the digital era, using gadgets to explore children's potential, recognizing technology for parents accompanying children in using the internet, preventing and recognizing children's game addiction, and preventing children from being entangled in pornography on the internet. 
Related to parenting, Queenrides also discussed how parents avoided toxic parenting which was dangerous for children's growth and development, especially in the COVID-19 pandemic period. For children growing up with toxic parenting, if they were not aware of that condition and heal their inner wounds, they continued to implement the toxic parenting pattern to their children [5]. Mistakes were repeated to the next generation. Childhood trauma was having parents who could not regulate their emotions. Stopping bad habits in the family could be done when parents were aware to heal wounds and decide not to repeat the same mistakes to their children.

In addition, an interesting theme that some people thought of as taboo and rarely discussed the issue, but was so crucial as a provision of knowledge for children [25] was sex education for toddlers. Many studies reported that sex education from an early age prevented the occurrence of early pregnancy, the transmission of HIV disease, and various other sicknesses [9], [15], [6]. Sex education was not only about sexual relationships but also about the introduction of body organs, organ anatomy, reproduction, infectious diseases, and others [34]. Sex education should be taught to children. Children needed their parents as a place to ask the various possibilities.

During the pandemic, children studied at home with the Distance Learning (PJJ) system. If many parents gave up $100 \%$ of their children's education to school before [29], now parents were forced to participate directly in their children's education. Parents should be able to train their children in discipline when learning from home. This transition period was not always easy but there was always a good ending in every condition. The pandemic had increased the parents' involvement in the children's education process. The ideal condition of education occurred when schools and parents had an equal role [4].

Another theme that was also discussed was how to manage children's emotional intelligence. Emotional intelligence was the ability to feel, convey, understand and manage emotions to support intellectual development [35]. This emotional intelligence should be preserved by children so that they grow up to be individuals who could lead and collaborate for having positive performance. Emotional intelligence also boosted a positive mood which had an impact on children's creativity in solving problems [14].

Besides learning to manage emotions, children also needed to be trained for having a tough mentality. They were central to be accustomed to struggling on their own, completing their tasks, accepting the bitterness of the results, as well as being ready to laugh and be disappointed. Iim Fahima said that based on her discussions with the child and adolescent psychologists, the rate of children and adolescents' suicidal ideation increased due to wrong parenting patterns where parents were always present as children's saviors which resulted in children not having mental toughness when facing difficulties.

In addition, some sessions were also provided discussing other themes such as how to explore children's interests and talent since every child tended to think, process, and understand information. In general, children's learning styles were divided into four types, namely visual, auditory, read or write, and kinesthetic [19], [24]. However, some combinations of learning styles also emerged. This theme was crucial to explore so that children were able to understand the material optimally.

For most children, academic subjects were a boring activity. Apart from being identical to memorizing, academic material was often presented without context and relevance to the children's current condition. Academic lessons were vital because at least they became general knowledge that supported children's future. Therefore, parents should know how to increase children's internal motivation related to their academics. 
UNESCO reported that Indonesia ranked second from the bottom in terms of literacy skills, meaning that Indonesian children's reading interest was very low. According to UNESCO data, the Indonesian children's reading interest was only $0.001 \%$. This meant that out of 1,000 Indonesian children, only 1 person was categorized as an avid reader [18]. The impact of a lack of reading was not only limited knowledge but also being easy to believe in hoaxes and being pitted against each other so that people's energy was used up for insignificant things that did not improve their quality of life.

Several factors affected children's low interest in reading. For example, they grew up in an environment that did not like reading so that they did not have good role models. Parents did not have the awareness that reading was essential so they were not moved to foster children's interest in reading. A lack of government and community initiative in creating libraries with interesting books also influenced children's low reading interest [11].

The reading habit was something that should be improved from home. Some questions related to this theme were discussed in the Queenrides sessions such as what were the first steps? How to anticipate if children were more interested in playing with gadgets than reading? How to make a child understand what she was reading? How to build a reading habit from home? Those points were elaborated on in a session provided by Queenrides.

\section{Conclusion}

Queenrides had a very big role in educating women during the pandemic period by providing online lecturers using WhatsApp at an affordable cost so that it was possible to be followed by many women from all over Indonesia, even the world. Queenrides offered many discussions with various relevant themes to women's everyday life to give a solution during the pandemic period. Queenrides focused on how women could be economically independent, mentally healthy, and able to be good educators for their children in their families.

\section{References}

[1] Arikunto, Suharsimi. Prosedur Penelitian Suatu Pendekatan Praktik. Jakarta: Rineka Cipta. (2006).

[2] Bravo-Baumann, Heidi. Livestock and Gender: A Winning Pair. Swiss Agency for Development and Cooperation 31. (2000).

[3] Creswell, Jhon W. Research Design: Qualitative, Quantitative and Mixed Method Approaches. Califonia: Sage Publications. (2009).

[4] Daheri, Mirzon, and Idi Warsah. "Pendidikan akhlak: relasi antara sekolah dengan keluarga." AtTurats: Jurnal Pemikiran Pendidikan Islam 13.2 (2019).

[5] Dunham, Shea M. Poisonous Parenting: Toxic Relationships Between Parents and Their Adult Children. Routledge. (2012).

[6] Emilda, Sri. "ANALISIS KESEHATAN REPRODUKSI PADA REMAJA." Jurnal Kesehatan dan Pembangunan 11.21 (2021).

[7] Fakih, Mansour. Analisis Gender Dan Transformasi Sosial. Yogyakarta : Insist Press, (2016).

[8] Hasan, Iqbal. Analisis Penelitian dengan Statistik. Jakarta : Bumi Aksara. (2004).

[9] Hasanah, Hasyim. "Pemahaman kesehatan reproduksi bagi perempuan: Sebuah strategi mencegah berbagai resiko masalah reproduksi remaja." Sawwa: Jurnal Studi Gender 11.2 (2016).

[10] Hubeis, Aida Vitalaya S. Pemberdayaan Perempuan Dari Masa Ke Masa, Bogor : PT Penerbit IPB Press. (2011). 
[11] Inten, Dinar Nur. "Peran Keluarga dalam Menanamkan Literasi Dini pada Anak." Golden Age: Jurnal Pendidikan Anak Usia Dini 1.1 (2017).

[12] Lips, Hilary M. Gender: The Basics. Routledge. (2018).

[13] Marsaid, M., Hidayat, M., \& Ahsan, A. "Faktor Yang Berhubungan Dengan Kejadian Kecelakaan Lalu Lintas Pada Pengendara Sepeda Motor Di Wilayah Polres Kabupaten Malang”. Jurnal Ilmu Keperawatan: Journal of Nursing Science. 1(2). (2013).

[14] Maryati, Ika. Hubungan Antara Kecerdasan Emosi dan Keyakinan Diri (Self-Efficacy) dengan Kreativitas pada Siswa Akselerasi. Diss. Universitas Muhammadiyah Surakarta. (2009).

[15] Meilani, Niken, Zahroh Shaluhiyah, and Antono Suryoputro. "Perilaku Ibu Dalam Memberikan Pendidikan Seksualitas Pada Remaja Awal." Kesmas: Jurnal Kesehatan Masyarakat Nasional (National Public Health Journal) 8.8 (2014).

[16] Moeloeng, Lexy J. Metode Penelitian Kualitatif. Bandung : PT Remaja Rosdakarya. (2017).

[17] Mulia, Musdah. Ensiklopedia Muslimah Reformis Pokok- pokok Pemikiran Untuk

Reintrerpretasi dan Aksi. Jakarta: Dian Rakyat. (2019).

[18] Pardosi, Binur Yuni Artha, Lastri Mura Rizki Manurung, and Raras Firdarianti. "Peran Mahasiswa Sebagai Volunteer Dalam Meningkatkan Kualitas Literasi Di Desa 3T." Aksara: Jurnal Ilmu Pendidikan Nonformal 7.2 (2021): 589-596.

[19] Putri, Wilda Octaria Neizar, Heni Rusnayati, and Unang Purwana. "Hubungan Gaya Belajar dengan Hasil Belajar Siswa pada Materi Usaha dan Energi." Seminar Nasional Fisika. Vol. 1. No. 1. (2020).

[20] Queenrides Tim. Queenrides Managing A "Mission-driven for-profits startup" during Pandemic. Jakarta. (2020).

[21] Rofiah, Nur. Nalar Kritis Muslimah: Refleksi Atas Keperempuanan, Kemanusiaan, dan Keislaman. Bandung: Afkaruna. (2020).

[22] Sabarguna,Boy S. Analisis Data pada Penelitian Kualitatif. Jakarta : Penerbit UI Press. (2008).

[23] Saptandari, Pinky. "Lima Tingkat Pemberdayaan Perempuan," Masyarakat Kebudayaan dan Politik, Th XII, No 2, April (1999).

[24] Saputri, Fajar Isnaeni. "Pengaruh Gaya Belajar Visual, Auditori, dan Kinestetik Terhadap Prestasi Bejajar Siswa." Jurnal Prima Edukasia 3.01 (2016): 25-36.

[25] Sebayang, Wellina, Destyna Yohana Gultom, and Eva Royani Sidabutar. Perilaku Seksual Remaja. Deepublish. (2018).

[26] Shihab, M. Quraish. Perempuan, Tangerang : Lentera Hati. (2018)

[27] Shihab, M. Quraish. Wawasan Al-Quran: Tafsir Tematik atas Pelbagai Persoalan Umat. Bandung : Mizan Pustaka. (2007).

[28] Showalter, Eleineed. Speaking of Gender. New York : Routledge. (1989).

[29] Solikhin, Nur. Rumahku, Madrasahku. Jakarta : LAKSANA. (2018).

[30] Subhan, Zaitunah. "Gender dalam Tinjauan Tafsir." Kafaah: Journal of Gender Studies 2.1. (2012).

[31] Subhan, Zaitunah. Menggagas Fiqh pemberdayaan Perempuan. Jakarta Selatan : El-Kahfi. (2008)

[32] Sugiyono, Memahami Penelitian Kualitatif. Bandung : CVAlfabeta. (2005).

[33] Tierney, Helen, ed. Women's studies encyclopedia. Vol. 1. Greenwood Publishing Group. (1999).

[34] Wahyuni, Dewi. "Peran Orang Tua Dalam Pendidikan Seks Bagi Anak untuk Mengantisipasi LGBT." Quantum: Jurnal Ilmiah Kesejahteraan Sosial 14.1 (2019).

[35] Wuwung, Olivia Cherly. Strategi Pembelajaran \& Kecerdasan Emosional. Surabaya : Scopindo Media Pustaka. (2020).

[36] The Interview Report with The Founder of Queenrides Indonesia Iim Fahima Jachja on Friday, July 162020

[37] www.bps.go.id accessed on May 21, 2021 at 11.39 
[38] www.queenrides.com accessed on May 21, 2021 at 11.44

[39] www.kominfo.go.id accessed on May 21, 2021 at 11.47

[40] www.katadata.co.id accessed on May 21, 2021 at 12.15 